Sains Malaysiana 49(8)(2020): 2005-2011

http://dx.doi.org/10.17576/jsm-2020-4908-23

\title{
Oil Extraction from Oil Palm Empty Fruit Bunches with Crystallization Technique
}

(Pengestrakan Minyak daripada Serabut Tandan Kosong Kelapa Sawit dengan Teknik Penyejukan)

\author{
Kessnia Ira Ng, Coswald Stephen Sipaut @ MoHd NASRI* \& Jidon AdRIAn JANAUn
}

\begin{abstract}
Oil palm empty fruit bunches (EFB) are the common by-product of palm oil mills as in 2017 approximately 87.721 million tons of EFB were produced. This abundance of EFB causes several problems, including pollution and pest infestation, which have an impact on the well-being of the environment and humanity. Due to this, research on EFB has been conducted, demonstrating its capability to be a sustainable resource for derived products, such as bio-oil and EFB fibre as composite filler. Research shows that processed EFB fibre contains 2-3\% of residual oil but current oil extraction methods require the use of either high temperature and/or high pressure. Existing methods require high energy consumption and are unable to extract all residual oil within EFB. Therefore, a new EFB oil extraction technique is proposed, based on the fundamental theory of crystallization as a separation method. This technique was able to achieve reductions of 74.45 and $30.03 \%$ in the oil yield from processed EFB using liquid nitrogen and standard refrigeration system as crystallization media, respectively.
\end{abstract}

Keywords: Nitrogen liquid; separation technique; standard refrigeration system

\section{ABSTRAK}

Serabut tandan kosong kelapa sawit (EFB) merupakan produk sampingan daripada industri kelapa sawit; lebih kurang 87.721 juta tan telah dihasilkan pada tahun 2017. Dengan jumlah sedemikian, EFB boleh menyebabkan pencemaran dan serangan serangga perosak. Ini boleh memberi kesan yang teruk terhadap bukan sahaja persekitaran malah kesihatan masyarakat sekeliling. Oleh sebab demikian, penyelidikan atas EFB telah dijalankan. Penyelidikan yang dijalankan telah menunjukkan bahawa EFB menpunyai potensi sebagai sumber mapan untuk produk berasaskan EFB; seperti minyak biologi dan serabut EFB sebagai pengisi komposit. Penyelidikan ini juga menunjukkan ia mempunyai sisa minyak kelapa sawit sebanyak 2-3\%. Tetapi teknik pengekstrakan minyak terkini memerlukan penggunaan tenaga seperti tekanan dan haba yang tinggi. Namun, ia tidak dapat mengekstrak minyak kelapa sawit sepenuhnya. Oleh itu, teknik pengekstrakan baru dicadangkan yang berasaskan teori asas penyejukan sebagai keadah pemisahan. Teknik ini menunjukkan pengurangan ekstrakan minyak sebanyak $74.45 \%$ dengan nitrogen cecair sebagai media penyejukan dan $30.03 \%$ dengan sistem penyejukan sebagai media penyejukan.

Kata kunci: Cecair nitrogen; sistem penyejukan; teknik pemisahan

\section{INTRODUCTION}

Palm oil empty fruit bunches (EFB) are the common and the most produced bi-product of palm oil industry. As palm oil fresh fruit bunches (FFB) are approximately consist of $20 \%$ of EFB, and it was estimated one tonne of EFB was produced with one tonne of palm oil (Chang 2014). Based on this estimation, there are 19.92 million tonnes of produced EFB in year 2017, as the crude palm oil (CPO) production are 19.92 million tonnes (Kushairi et al. 2018). Abundant EFB production makes it a promising candidate for a sustainable resource of yielding high-end derived products, such as fibreboard, fibre for both composite filler and cushion industries, and bio-oil production. However, current oil extraction technique is unable to completely extract oil residual within EFB fibre. The reminder oil residual within EFB fibre will started emitted unpleasant scent overtime. In which will be rendering industries (especially mattress and cushion industries) unable to commercialise products derived from EFB fibre. Due to this, EFB fibre was not considered as lucrative end products. Apart from this, extracted bio-oil from EFB with current extraction technique produced uncertainty in its production. As the extracted bio-oil are either high yield with low quality, or vice versa (Purwanto et al. 2015; Sukiran et al. 2009; Yun \& Dupont 2015). Although the current extraction technique used necessitates operation in both high pressure and high thermal condition, in which this 
condition highly discourage by industry as it contributed to greater production costs. Due to this, the abundant EFB are currently been used as boiler fuel in palm oil mill, with its ashes was used as fertilizer or soil conditional (Yusoff 2006). However, incineration by-product of EFB are not been fond upon, as their contribution towards air pollution with excessive emission of white smoke. Hence, abundant EFB are left to rot within palm oil plantation as wasting their full potential. An improved extraction technique would benefit EFB derived products. This is possible to achieved with the understanding of current extraction technique and EFB properties. The extracted oil residual will detach from EFB fibre with the introduction of kinetics energy towards its molecular bonds. Where kinetic energy will loosen molecular bonds that acting between EFB component and oil residual molecules. Thermal energy is commonly been used to induce the required kinetic energy, in which its was one of important key factor in oil extraction technique. However, with exposure towards thermal energy, the oil-sorption mechanism within EFB fibre are activated as well, as the absorption rate increase with applied temperature (Md. Yunos et al. 2015). Oil-sorption mechanism take place as oil residual coated on surface of EFB and over time, oil residual will be retained within pores, as it started to infuse with EFB component. Due to this mechanism, most of oil residual can be found within spikelet (Gomez et al. 2014) and stalk (Md. Yunos et al. 2015). This will impede the oil extraction techniques that required thermal energy.

Even though the use of thermal energy hinders the oil extraction technique effectiveness towards $\mathrm{EFB}$, it provides better theoretical understanding of oil extraction mechanism acting upon EFB and the molecular forces and bonds acting between oil residual molecules and EFB component. From this understanding, it is likely that temperature manipulation could be used to extract oil residual from EFB. As temperature reduction could contribute to the required kinetic energy in oil extraction technique. The reduction will lead activation of crystallization mechanism, as it crystallized the molecular bond that acting between oil residual and EFB component, which will restrict the molecular movement. Where in this condition, the crystallized oil residual and EFB are very venerable towards physical disruption (Chaudhary 2013). In which physical disruption provide vibrational motion that induced the stress cracking. That will lead the possibility of oil residual detachment from EFB. Hence, this study is setup to further understand this fundamental theory, with the hope of developing a new method of oil extraction from EFB using a crystallization technique.

\section{MATERIALS AND METHODS}

Crystallization time of crude palm oil (CPO) are determined with cooling systems. Crude palm oil (CPO) was obtained from Taner R\&D Palm Oil Mill, Tenom Sabah. Two crystallization media were used: liquid nitrogen and a standard refrigeration system. For the standard refrigerator system, CPO was placed into a test tube with a thermometer probe (digital voltmeter; Victor $86 \mathrm{~B}$ ), before being placed into the refrigerator (Upson, Model no. UFZ-300). For the liquid nitrogen crystallization medium, the cooling system required design and fabrication. It was important to retain the surrounding cooling temperature for $\mathrm{CPO}$ in order to minimize error due to the high difference between external and system temperatures. The system consisted of a polyester box containing liquid nitrogen as the crystallization medium, as shown in Figure 1.

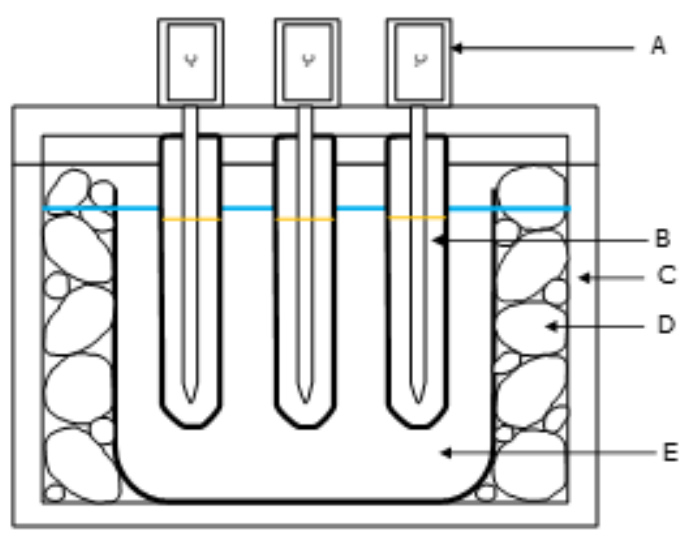

FIGURE 1. The cooling system for liquid nitrogen as crystallization medium; A is the thermometer, $\mathrm{B}$ is the CPO, $\mathrm{C}$ is the polyester box, $\mathrm{D}$ is the mixture of ice and liquid nitrogen, and $\mathrm{E}$ is the liquid nitrogen 
Crystallization technique on EFB fibre are conducted with liquid nitrogen and standard refrigerator system as its crystallization media. Processed EFB fibre was collected at Desa Kim Loong Palm Oil Mil, Nabawan Keningau, Sabah; where fibre samples were taken after pressing by an EFB press machine. Crystallization on EFB with liquid nitrogen was conducted in a similar experimental setting as shown in Figure 1 except that the thermometers and $\mathrm{CPO}$ test tubes were replaced with EFB fibre. For crystallization using the standard refrigerator system, the EFB were placed inside a sealed polyethylene bag before being put inside the refrigerator.

Extracted oil yield from EFB are conducted with soxhlet extraction. Both EFB fibre and crystallized EFB fibre were placed in a soxhlet extractor to extract their residual oil. Approximately 4 to $6 \mathrm{~g}$ of EFB fibre was weighed and placed into the extraction siphon. $\mathrm{N}$-hexane solvent (AR grade, Merck) was used as the solvent and extraction was conducted for $8 \mathrm{~h}$ before placement into rotary vapour for a further $3 \mathrm{~h}$. The obtained oil was placed into an oven for $3 \mathrm{~h}$ for complete hexane removal. The weight of residual oil was calculated with the following formula:

$$
\text { Oil residual content }(\%)=\frac{\text { Weight of oil }(\mathrm{g})}{\text { EFB sample }(\mathrm{g})} \times 100 \%
$$

\section{RESULTS AND DISCUSSION}

In order to develop oil extraction with crystallization technique, thermal profile of CPO required to be analysed, as CPO had similar properties as oil extracted from EFB (Md. Yunos et al. 2015). The thermal profile for CPO is done with DSC cooling thermogram, where study conducted by Che Man et al. (1999), showed temperature peaks in the ranges of -48.62 to $-60.36{ }^{\circ} \mathrm{C},-25.89$ to $-29.19{ }^{\circ} \mathrm{C}$ and -11.22 to $-1.69{ }^{\circ} \mathrm{C}$. These ranges were used as the target for crystallization temperature. With this, two types of crystallization medium (liquid nitrogen and standard refrigeration system) were chosen, where liquid nitrogen will cover all of the temperature ranges, as it had the boiling point of $-196{ }^{\circ} \mathrm{C}$. While standard refrigeration system targeted the temperature range of -11.22 to $-1.69{ }^{\circ} \mathrm{C}$, as it had the temperature average of -18 to $-16^{\circ} \mathrm{C}$.

Apart from these temperature ranges as the key factor of choosing the crystallization medium type, the amount of heat transfer between crystallization medium and crystallized material (EFB and $\mathrm{CPO}$ ) was taken into consideration. As exposure towards rapid temperature difference will lead the intermolecular force increment, which lead the only existence of vibrational molecular within molecular bond (Chaudhary 2013). This motion is generated by physical force disruption, in which cause crystallized material to be fragile towards any applied physical force (Chaudhary 2013). This theoretical knowledge can be easily achieved by using liquid nitrogen as crystallization medium. However, the rapid temperature difference in $\mathrm{CPO}$ with liquid nitrogen as crystallization medium, can result in error in data collection.

To combat this error, two measures had taken place by introducing standard refrigeration system as crystallization medium and cooling system for liquid nitrogen as crystallization medium are designed to mimic the standard refrigeration system. Standard refrigeration system will able to provide much control temperature drop reading, in which it was designed to seal its crystallization environment. This will significantly reduce error caused temperature difference due to surrounding room environment. With this design in mind, cooling system for liquid nitrogen was designed as a closed system built from a polyester box; whose lid was sealed throughout the experiment. The thermometer was inserted through the lid to determine the crystallization temperature with the respect to time. The CPO crystallization time using liquid nitrogen as crystallization medium was determined with a crystallization temperature range of -55 to -65 ${ }^{\circ} \mathrm{C}$. This temperature range was set as the temperature target. The experiment was stopped as soon it reached this temperature range, without letting the system reach an adiabatic state. This is because the thermometer used in this experiment had a temperature range detection capacity of -70 to $300{ }^{\circ} \mathrm{C}$.

Figure 2 shows a trend of decreasing temperature with time of exposure to the standard refrigeration system. In the first five min, a steep reduction in temperature is observed, indicating high heat transfer between the CPO sample and the cooling system. During this time, the cooling system was in the temperature range of -17.3 to $-18.5^{\circ} \mathrm{C}$ and the $\mathrm{CPO}$ sample had an average temperature of $23.5^{\circ} \mathrm{C}$. After this steep decrease, a more constant temperature was observed at around 30 to $40 \mathrm{~min}$, indicating that the system had reached its adiabatic state where no heat transfer can occur. The CPO sample also reached the target temperature in the time range of 30 to $40 \mathrm{~min}$. Therefore, the crystallization time of $\mathrm{CPO}$ to reach the target temperature range of -15 to $-16{ }^{\circ} \mathrm{C}$ as $35 \mathrm{~min}$. Figure 2(b) shows an almost linear trend within the time range of $80 \mathrm{~s}$, indicating a high rate of heat transfer between the cooling system and CPO sample which occurred due to the high temperature difference between them. The CPO sample appeared solid and brittle after the immersion of liquid nitrogen. These material attributes are similar to those obtained with flash freezing, where exposure to extremely low temperature causes brittleness in the applied material.

The CPO crystallization times were determined to be $60 \mathrm{~s}$ and $35 \mathrm{~min}$ for the liquid nitrogen and standard refrigerator systems, respectively. Since it was believed that the residual oil within EFB has similar physicochemical properties to CPO (Md. Yunos et al. 2015), these CPO crystallization times were used as the crystallization times to conduct oil extraction from EFB using crystallization. Residual oil from both CPO 
and EFB contains the same main fatty acid compounds: palmitic acid, oleic acid, linoleic acid, and stearic acid. This similarity could result from stripping and threshing processing of sterilized FFB, where palm oil fruitlets are removed from their branches. The applied sterilization temperature $\left(140^{\circ} \mathrm{C}\right)$ on FFB causes the palm oil to leak out from the palm oil fruitlet (Abdullah \& Sulaiman 2013), forming a coating on the EFB surface, where oil-sorption takes place. This mechanism is known as face adsorption (Carmody et al. 2007). The oil coating makes the surface waxy, producing a high water contact angle which contributes to its hydrophobic properties (Md. Yunos et al. 2015). Over time, a second oilsorption mechanism starts to occur: The inter-capillaries mechanism, where oil moves and is retained within the surface pores of EFB (Carmody et al. 2007). The retained oil is then infused with EFB component matrix, where it fuses during the stripping and threshing process of sterilized FFB that produces EFB as the solid by-product of palm oil mill. EFB fibre oil-sorption mechanisms also indirectly contribute to the residual oil removal efficiency. For the face adsorption mechanism, Lim and Huang (2007) stated that a waxy fibre surface contributes to high residual oil removal efficiency. Regarding the inter-capillaries mechanism, Karan et al. (2011) stated that fibre with high porosity will have poor retention capacity but higher initial oil uptake, making residual oil within the EFB easier to remove.

\section{OIL EXTRACTION FROM EFB USING CRYSTALLIZATION TECHNIQUE}

Oil extraction from EFB using crystallization technique was performed by crystallizing EFB fibre within a

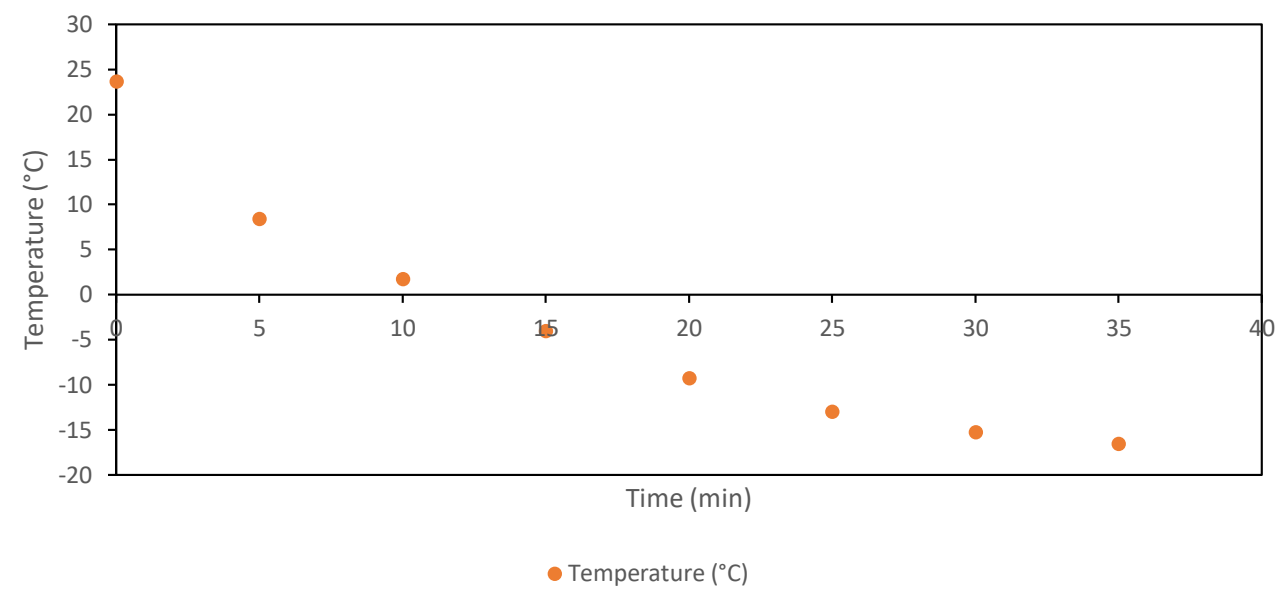

(a)

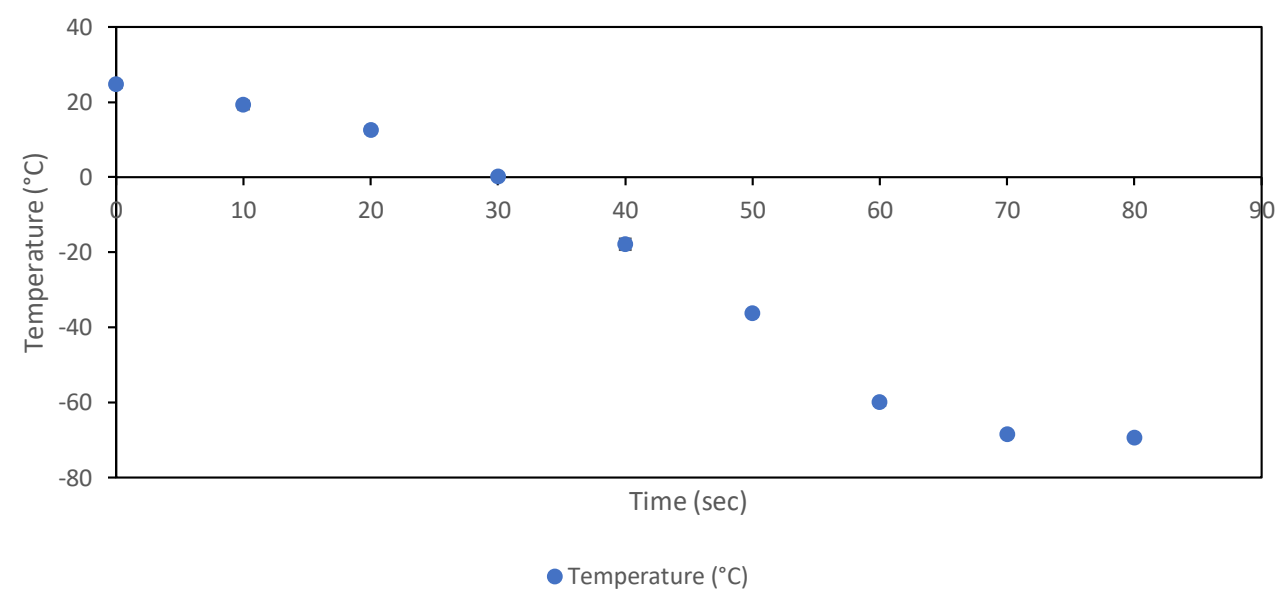

(b)

FIGURE 2. Crystallization of CPO with respect to time using (a) standard refrigeration system and (b) liquid nitrogen as crystallization medium 
crystallization medium using the established CPO crystallization time. The crystallized EFB fibre was placed into a mechanical shaker and shaken for $5 \mathrm{~min}$. After this process, the EFB fibre was considered to be cleaned EFB fibre. Cleaned EFB fibre was then placed into a soxhlet extractor to determine its oil yield content. The EFB fibre residual oil yield for each crystallization medium is as shown in Table 1 and Figure 3.

Figure 3 shows that crystallization strongly affects the residual oil content of EFB fibre, as demonstrated by significantly reduced oil yield after crystallization process with either media. This reduction in oil yield shows the amount of oil remaining within the cleaned EFB fibre. Crystallization using liquid nitrogen had an oil yield reduction of $74.54 \%$, while with the standard refrigerator produced a $30.03 \%$ oil yield reduction, as compared to EFB fibre before the process. Table 1 and Figure 3 show that the application of crystallization to EFB oil extraction is possible. The application of fundamental crystallization theory to oil extraction from EFB shows potential as a new oil extraction technique. In fundamental theory, crystallization is commonly used in substance purification, where it separates solid from solution, with or without temperature application (BYJU'S 2019). However, this technique is usually used in liquid mixtures, where the liquid contains more than one component with different boiling or freezing temperatures (SoliQz 2014). These temperature differences are important as they correspond to the change one of the components into a different state of matter - for example, liquid to solid state. This difference in material state make it easier to separate and collect the desired products, which for this study are both cleaned EFB and residual oil.

The exposure of EFB fibre to liquid nitrogen is prone to increase the brittleness of oil when it experiences a rapid temperature drop. Rapid temperature drops may cause rapid changes in material state, in this case liquid to solid state. This experience is caused by the changes in the mobility chain of its components, which happen when molecules are unable to reach their preferred points due to a rapid cooling rate. The rapid changes can also cause tension between the molecules within a material, contributing to similar mechanisms as thermal cracking stress. Thermal cracking stress occurs during the expansion or contraction of a material by exposure to a sudden high temperature difference (Farlex 2003). In this state, the materials are only subjected to vibrational motion (Chaudhary 2013). Vibrational motion is oscillating motion that causes the molecules to move back and forth. This motion requires an external force or physical disruption to the molecule and with this sudden external force, the bonds between molecules are broken. In this study, the molecular bonds that could be strong are between the oil residual molecule and EFB component molecule.

The brittle attribute can also be shown in the molecular bond between EFB fibre and residual oil. Karan et al. (2011) showed that the hydrocarbons between the oil and fibre are held with Van der Waals forces, which are the weakest form of intermolecular attraction (Than 2013) and can thus be easily be broken with physical disruption (Md. Yunos et al. 2015). Exposure to the crystallization medium could also contribute to the molecular bond between the residual oil and EFB component, since crystallized residual oil is subject to contraction as it becomes solid. In addition, residual oil density increased with low temperature exposure (LIPICO Technologies 2008), which indicated that its weight increased as well. The increased weight of residual oil with Van der Waals bonds with EFB can be effortlessly broken with physical disruption.

TABLE 1. Extracted oil yield (\%) of EFB before and after crystallization process

\begin{tabular}{llcc}
\hline \multicolumn{1}{c}{ Process } & Oil yield (\%) & Standard deviation \\
\hline Before & Crystallization medium & 0.7765 & 0.0525 \\
& Standard Refrigeration System & & \\
After & Liquid Nitrogen & 0.5433 & 0.0534 \\
& & 0.1977 & 0.0011 \\
\hline
\end{tabular}




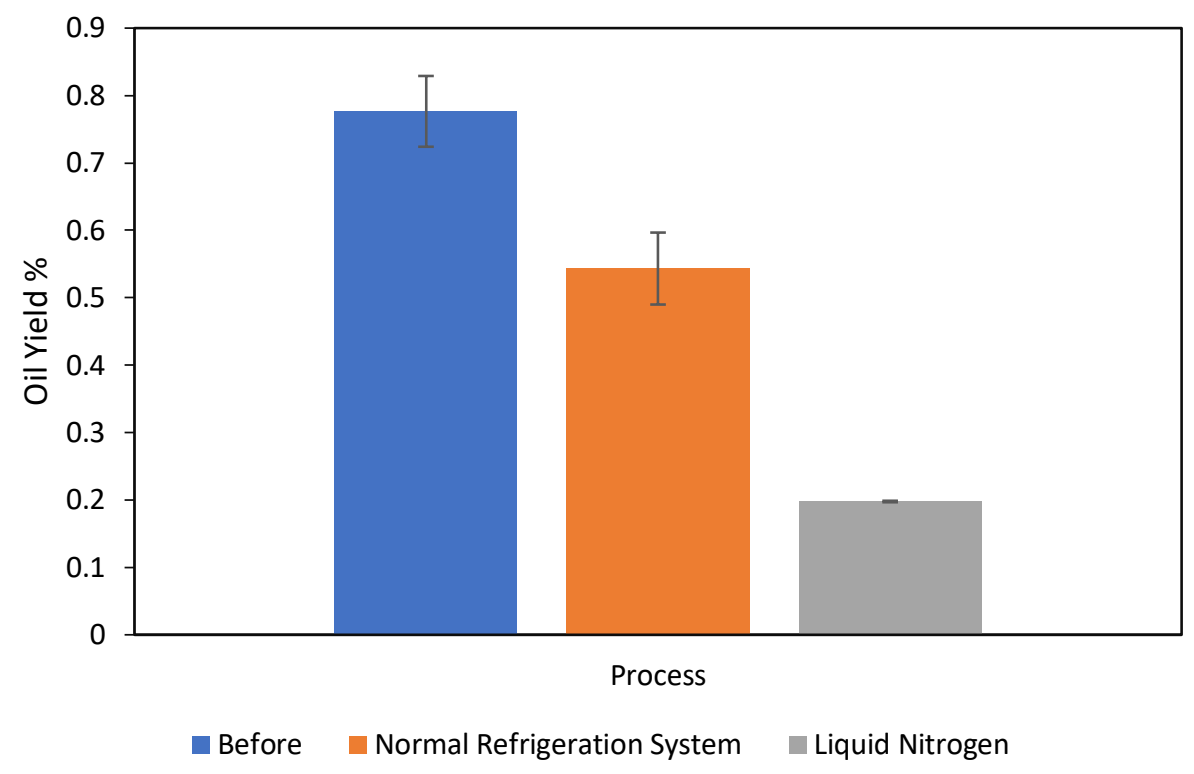

FIGURE 3. Extracted oil yield (\%) of EFB before and after crystallization process

\section{CONCLUSION}

This study found that the technique of crystallization had great potential to be applied to EFB residual oil extraction, as shown by the reduction in oil yield from crystallized EFB fibre, especially using liquid nitrogen as crystallization medium.

\section{ACKNOWLEDGEMENTS}

The authors would like to thank Kementerian Pendidikan Tinggi, Malaysia and Universiti Malaysia Sabah for providing research financial assistance; Fundamental Grant Scheme Fund (FRG0471/2017) and UMSGreat (GUG0113-1/2017). Also thank to UMS Centre of Instrumentation and Science Service for research assistance.

\section{REFERENCES}

Abdullah, N. \& Sulaiman. F. 2013. The oil palm wastes in Malaysia. IntechOpen. pp. 75-93.

BYJU'S. 2019. Crystallization. https://byjus.com/chemistry/ crystallization/. Accessed on 19 March 2019.

Carmody, O., Frost, R., Xi, Y. \& Kokot, S. 2007. Surface characterisation of selected sorbent materials for common hydrocarbon fuels. Surface Science 601(9): 2066-2076.

Chang, S.H. 2014. An overview of empty fruit bunch from oil palm as feedstock for bio-oil production. Biomass and Bioenergy 62 (2014): 174-181.

Chaudhary, V. 2013. Fundamental studies of the effect of glass transition temperature on enzymatic activity in high-solid biomaterials. PhD Thesis. RMIT University (Unpublished).
Che Man, Y.B., Haryati, T., Ghazali, H.M. \& Asbi, B.A. 1999. Composition and thermal profile of crude palm oil and its products. Journal of the American Oil Chemists' Society 76(2): 237-242.

Farlex, I. 2003. Thermal Stress Cracking. https://encyclopedia2. thefreedictionary.com/thermal+stress+cracking. Accessed on 20 March 2019.

Gomez, J.C., Mokhtar, M.N., Sulaiman, A., Zakaria, R., Baharuddin, A.S. \& Busu, Z. 2014. Study on residual oil recovery from empty fruit bunch by combination of water and steam process. Journal of Food Process Engineering 38(4): 385-394.

Karan, C.P., Rengasamy, R.S. \& Das, D. 2011. Oil spill cleanup by structured fibre assembly. Indian Journal of Fibre \& TExtile Research 36: 190-200.

Kushairi, A., Loh, S.K., Azman, I., Elina, H., Ong-Abdullah, M., Balu, N., Zanal, I., Razmah, G., Vijaya, S., Shamala, S. \& Ahmad Parveez, G.K. 2018. Oil palm economic performance in Malaysia and R\&D progress in 2017. Journal of Oil Palm Research 30(2): 163-195.

Lim, T.T. \& Huang, X. 2007. Evaluation of Kapok (Ceiba pentandra (L.) Gaertn.) as a natural hollow hydrophobicoleophilic fibrous sorbent for oil spill cleanup. Chemosphere 66(5): 955-963.

LIPICO Technologies. 2008. Technical References - Palm Oil Properties. http://www.lipico.com/technical_references_ palm_oil_properties.html. Accessed on 20 March 2019.

Md. Yunos, N.S.H., Samsu Baharuddin, A., Md. Yunos, K.F., Hafid, H.S., Busu, Z., Mokhtar, M.N., Sulaiman, A. \& Md. Som, A. 2015. The physicochemical characteristic of residual oil and fibres from oil palm empty fruit bunches. 
BioResources 1(10): 14-29.

Purwanto, W.W., Supramono, D., Muthia, R. \& Firdaus, M.K. 2015. Effect of biomass types on bio-oil characteristics in a catalytic fast pyrolysis process with a Ni/ZSM-5 catalyst. International Journal of Technology 6(7): 1069-1075.

SoliQz, B.V. 2014. Separation by Crystallization. https://www. soliqz.com/crystallization/separation-by-crystallization/. Accessed on 19 March 2019.

Sukiran, M.A., Chin, C.M. \& Bakar, N.K.A. 2009. Bio-oils from pyrolysis of oil palm empty fruit bunches. American Journal of Applied Science 6(5): 869-875.

Than, J. 2013. Van Der Waals Interactions. https:/chem.libretexts. org/Bookshelves/Physical_and_Theoretical_Chemistry_ Textbook_Maps/Supplemental_Modules_(Physical_and_ Theoretical_Chemistry)/Physical_Properties_of_Matter/ Atomic_and_Molecular_Properties/Intermolecular Forces/Specific_Interactions/Van_Der_Waals_Interactions. Accessed on 20 March 2019.
Yun, H.A.H. \& Dupont, V. 2015. Thermodynamic analysis of methanation of palm empty fruit bunch (PEFB) pyrolysis oil with and without in situ $\mathrm{CO}_{2}$ sorption. AIMS Energy 3(4): 774-797.

Yusoff, S. 2006. Renewable energy from palm oil - Innovation on effective utilization of waste. Journal of Cleaner Production 14(1): 87-93.

Faculty of Engineering

Universiti Malaysia Sabah

Jalan UMS, 88400 Kota Kinabalu, Sabah

Malaysia

*Corresponding author; email: css@ums.edu.my

Received: 21 October 2019

Accepted: 4 April 2020 